\title{
Exploring drying conditions for Mexican mesquite pods (Prosopis laevigata)
}

\section{Sandoval, S.; López, D.; Rodríguez, J.; Méndez, L.; Aquino, L. V.}

Instituto Politécnico Nacional, CIIDIR Unidad Oaxaca. Hornos No. 1003, Col. Noche Buena, Santa Cruz Xoxocotlán, CP. 71230. Oaxaca, México.

*E-mail of the corresponding author: ssandovalt@ipn.mx

\begin{abstract}
Mesquite pods contain a high nutritional content, then a protein rich flour can be obtained. Prosopis Laevigata pods were collected from Oaxaca and Durango. Three stages of maturity were identified. The internal structure of the pods was analyzed by scanning electron microscopy (SEM). The pods were dried at $40^{\circ} \mathrm{C}, 50^{\circ} \mathrm{C}$ and $60^{\circ} \mathrm{C}, 10 \%$ relative humidity and air velocity of 2.6 $\mathrm{m} / \mathrm{s}$. From experimental data, the characteristic curve was obtained. SEM Images showed a heterogeneous and tortuous structure. The internal structure of the material is a limiting factor for mass transfer. The effective coefficient diffusion for each drying experiment was determinated.
\end{abstract}

Keywords: Drying; mesquite; pods. 


\section{Introduction}

The mesquite is an extremophile tree that grows in arid and semi-arid zones around the world. In Mexico, mesquite is found in northern, central and southern states of the country and in the past was used as a bread, flour, and syrup [1]. The pods having a high content of protein, sugar, calcium, iron and fiber present a wide potential in the development of food products [2]. In order to process the pods a specific drying process is mandatory. Mesquite pods are a highly hygroscopic material due to the high sugar content [3]. The pods have a low moisture content ( $0.14 \mathrm{~g}$ water / $\mathrm{g}$ dry mater); however they tend to absorb moisture quickly in humid environments. After drying pods should at least reach a moisture content of $0.06 \mathrm{~g}$ water $/ \mathrm{g}$ dry matter, otherwise they cannot be efficiently milled [4].

\section{Materials and Methods}

Prosopis laevigata pods were harvested between April and August 2017 in Oaxaca and Durango (Mexico). The color was measured with a HunterLab Model E-Z spectrophotometer using the CIELab color scale. In the CIELab color scale, the parameter L* represents the luminosity of the material; the parameter $\mathrm{a}^{*}$ represents changes of coloration from red to green, and the parameter $b^{*}$ indicates a coloration that goes from yellow to blue. The sugars were quantified following the method NMX-F-312-1978. The mesquite pods were analyzed by electron microscopy, using a JEOL brand electronic scanning microscope (SEM), model JIB-4601F, with a spatial resolution of $1.2 \mathrm{~nm}$. Pods without deterioration were selected for drying. The moisture content of the pods was measured by the oven-dry method (NMX-F083-1986).

The pods were dried in a tunnel dryer (patent 304462). The temperature, relative humidity, and air velocity were controlled and logged. A National Instrument FP-1000 system was used, in order to log the data. The temperature of the material was measured using J-type thermocouples (Vaisala Veriteq SP 1700). A steam generator model TV / G2F Anghinetti SRL was used for the humidification of the air. Only pods from Oaxaca in stage 3 were dried at three different temperatures $\left(40^{\circ}, 50^{\circ} \mathrm{C}\right.$ and $\left.60^{\circ} \mathrm{C}\right)$ and the Durango pods in stage 3 were dried only at $60^{\circ} \mathrm{C}$. Drying experiments were conducted at constant relative humidity $(10 \%)$ and air velocity of $2.6 \mathrm{~m} / \mathrm{s}$.

\subsection{The characteristic drying curve.}

The experimental kinetics were normalized and the characteristic drying curve was obtained. The reduced moisture content was computed as follows:

$$
W_{r}=\frac{W_{t}-W_{e q}}{W_{i}-W_{e q}}
$$


A polynomial equation of order 6 was used to depict the experimental drying kinetics, after that the drying rate was computed. The reduced drying rate $(\mathrm{dWr})$ was calculated by using dWref:

$$
d W r=\frac{d W}{d W_{r}}=\left[-\frac{d W}{d t}\right]_{r}=f\left(W_{r}\right)
$$

According to Equation 2, the reduced drying rate $\mathrm{dWr}$ is a function of the reduced moisture content $\mathrm{Wr}$, so an equation is derived to describe the complete kinetics using the following conditions:

$$
\begin{aligned}
& f\left(W_{r}\right)=0 \text { if } W_{r}=0 \\
& 0<f\left(W_{r}\right)=<1 \text { if } 0<W_{r}<1 \\
& f\left(W_{r}\right)=1 \text { if } W_{r}=1
\end{aligned}
$$

The graphs of reduced moisture content versus reduced drying rate can be described with a straight line for both Oaxaca and Durango pods ranging from reduced moisture content of 1 to 0.01 . The initial phase of the of drying rate curves are discarded since it happens very fast and the final period is not taken into account by the model because it represents very low moisture contents [5]. The deduction of the linear model is presented below:

$$
W=C+\left(W_{r 0}-W_{e q}\right)\left[\left(1+\frac{d}{c}\right) e^{\frac{-C * d W r e f * t}{W_{r 0}-W_{e q}}}-\frac{d}{c}\right]
$$

\section{Results and Discussion}

According the Cielab scale, three stages of maturity were defined (Table 1). In Stage 1 pods show a green coloration, in stage 2 the pods are brighter with a reddish coloration. In stage 3 the pods increase in brightness compared to the previous stages, reddish and yellow coloration is still observed, but in a lower intensity compared to stage 2 .

Table 1. CIElab color parameters of mesquite pods at different stages of maturity

\begin{tabular}{cll}
\hline Stage 1 & \multicolumn{1}{c}{ Stage 2 } & \multicolumn{1}{c}{ Stage 3 } \\
\hline $\mathrm{L}^{*} 70.75+/-0.6632$ & $\mathrm{~L}^{*} 71.46+/-0.8423$ & $\mathrm{~L} * 73.87(2017)+/-0.5754$ \\
\hline $\mathrm{a} *-45.84+/-0.1567$ & $\mathrm{a}^{*} 8.68+/-0.3214$ & $\mathrm{a} * 3.66(2017)+/-0.1345$ \\
\hline $\mathrm{b} 64.78+/-0.4892$ & $\mathrm{~b}^{* 71.13+/-0.5919}$ & $\mathrm{~b} * 26.4(2017)+/-0.2598$ \\
\hline
\end{tabular}

The content of sugars (Table 2) in the three stages of maturity has significant differences; the green pods have a bitter taste, while the mature pods have a sweeter taste. Stage 1 pods have less sugar than other stages of maturity also a bitter taste which isn't good for further processing, stage 2 pods have a higher sugar content however their moisture content $(3.08 \mathrm{~g}$. 
water/g. dry matter) makes them difficult to dry and a high moisture content after drying makes them unusable for further processing; pods in stage 3 have a sugar content that makes them sweet and a moisture content of $0.22 \mathrm{~g}$. water $/ \mathrm{g}$. dry matter. Pods from Durango in stage 3 have a significantly higher sugar content than pods from Oaxaca which prolongs the drying time due the hygroscopic behavior of the sugars on the mesocarp.

Table 2. Sugar content in the different states mesquite pods

\begin{tabular}{ccccc}
\hline $\begin{array}{c}\text { 100 g of } \\
\text { Pods. }\end{array}$ & Stage 1 (Oaxaca) & Stage 2 (Oaxaca) & Stage 3 (Oaxaca) & Stage 3 (Durango) \\
\hline Sugars. & $6.55 \mathrm{~g}+/-0.0680$ & $8.15 \mathrm{~g}+/-0.3552$ & $7.42 \mathrm{~g}+/-0.1305$ & $14.42 \mathrm{~g}+/-0.1178$ \\
\hline
\end{tabular}

The seeds (Fig. 1) are covered by the endocarp; they have a semi-spherical, brown, smooth and shiny texture. In Fig. 2 a) we observe a cross section of the seed where the tegument constituting the outermost layer of the seed, the endosperm is divided into different sections each with similar structure, finally the embryo is observed in the central and inner part of the seed. The seed measures $2.5 \mathrm{~mm}$ thick. In Fig. $2 \mathrm{~b}$ ) we observe the surface of the tegument presenting a homogeneous conformation with no pores. In Fig. 2 c) the image shows the back part of the tegument as well as the plumule. In Fig. 2 d) we can observe the space between and the endocarp where the seed is contained.

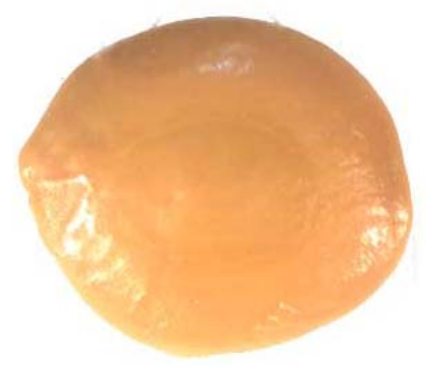

Fig. 1 Longitudinal image of the seed.

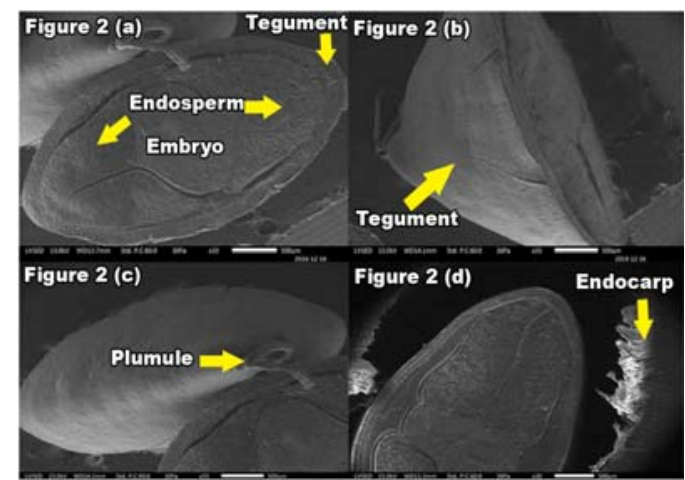

Fig. 2 Transverse images of the seed obtained by SEM.

The mesocarp thickness varies from each pod. This domain is rich in carbohydrates and has a highly hygroscopic nature [6]. It presents a tortuous, rubbery structure and cavernous sections. It is strongly attached to the endocarp and epicarp.

Figure 3 a) shows a section of the mesocarp, which has a heterogeneous, tortuous and rubbery conformation; these characteristics together with the hygroscopic capacity represent a further difficulty in the removal of moisture during drying. Figure $3 \mathrm{~b}$ ) presents a section of the mesocarp attached to the inner layer of the epicarp, showing an irregular, tortuous, heterogeneous and rubbery structure; strongly adhered to the epicarp. Figures $3 \mathrm{c}$ ) and $3 \mathrm{~d}$ ) 
show a cross section of the pod focusing on the mesocarp, again showing an irregular,

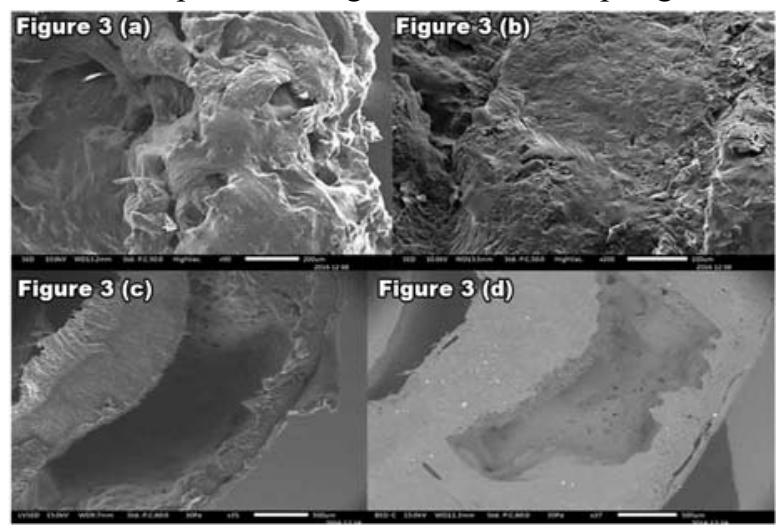

Fig. 3 Transverse images of the mesocarp obtained by SEM.

heterogeneous and tortuous conformation; presenting cavernous portions that present a further difficulty when predicting how moisture diffuses towards the surface.

In Fig. 4, we show the kinetics for the drying condition at $40^{\circ} \mathrm{C}$ and $50^{\circ} \mathrm{C}$. The pods reached the equilibrium moisture content $(\mathrm{W})$ at different times.. An inconvenience of drying at 40 and $50^{\circ} \mathrm{C}$ is the high moisture content at the end of drying, since a milling process requires pods with a very low moisture content.

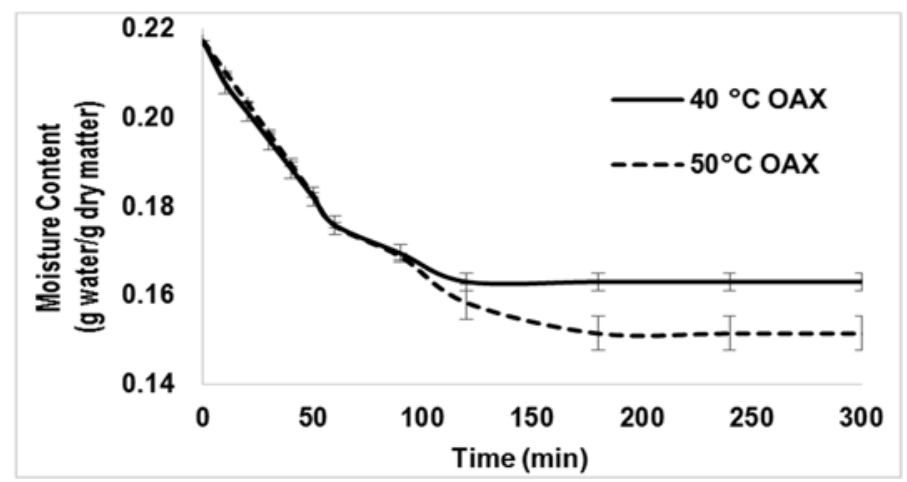

Fig. 4 Drying kinetics of mesquite pods stage 3 at $40{ }^{\circ}$ and $50^{\circ} \mathrm{C}$ (Oaxaca).

In Fig. 5 we observe the drying kinetics for drying at $60^{\circ} \mathrm{C}$ for pods from Oaxaca and Durango. The pods from Oaxaca had an initial moisture content of $0.2234 \mathrm{~g}$ water/g dry matter, meanwhile the Durango pods an initial moisture content of $0.1815 \mathrm{~g}$ water/g dry matter. In spite of a fast heating period, pods offer an important resistance to moisture 
migration due to its microstructure. During the heating period of drying where the evaporation rate increases, the free water diffuses more easily.

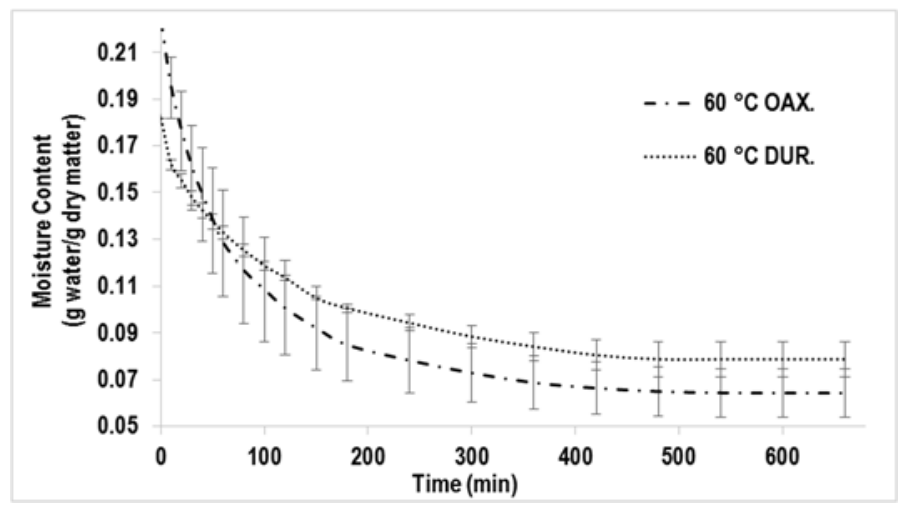

Fig. 5 Drying kinetics of mesquite pods stage 3 at $60^{\circ} \mathrm{C}$ (Oaxaca and Durango).

Table 3 shows the parameters obtained by the characteristic curve model. Figures 6 and 7 show the experimental drying kinetics of Oaxaca and Durango at $60^{\circ} \mathrm{C}$ and the characteristic curve.

Table 3. Calculated parameters of the characteristic drying curve model.

\begin{tabular}{cccc}
\hline Temperature $^{\circ} \mathbf{C}$ & dWref & c & d \\
\hline Oaxaca 60 & \\
& 0.0022 & 1.0488 & 0.0014 \\
\hline Durango 60 & \\
& & & \\
\end{tabular}

The characteristic curve (Fig. 6 and 7) shows a good agreement with the experimental data for drying at $60^{\circ} \mathrm{C}$ (Oaxaca) and $60^{\circ} \mathrm{C}$ (Durango). This empirical model has the advantage of predicting how pods are dried without the need to know all their properties. 


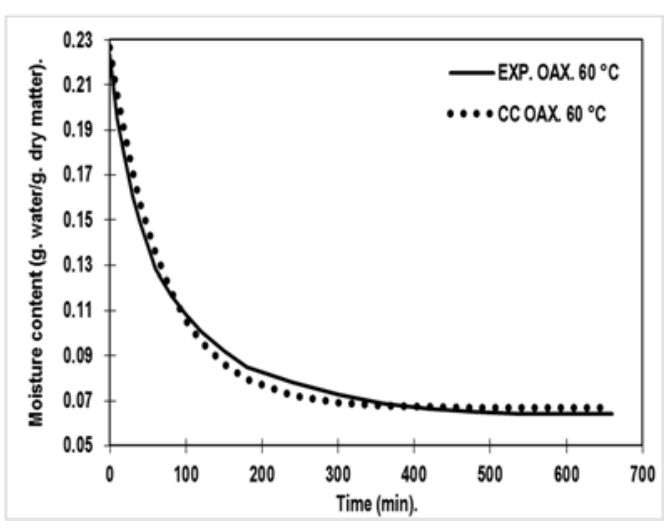

Fig. 6 Comparison of experimental data and the characteristic curve model (Oaxaca $60{ }^{\circ} \mathrm{C}$ ).

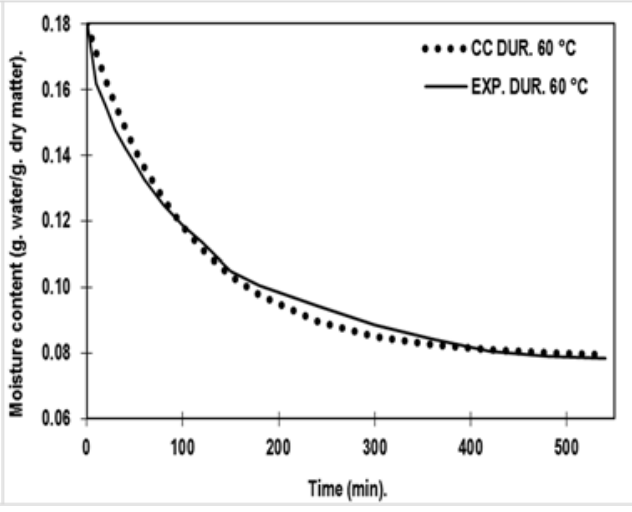

Fig. 7 Comparison of experimental data and the characteristic curve model

(Durango $60^{\circ} \mathrm{C}$ ).

\section{Conclusions}

The drying process of mesquite pods (Prosopis laevigata) was studied. Three stages of maturity were identified and the internal structure of the pod which plays a very important role in drying. The periods of maturity are followed by physical changes such as color and chemical changes such as the sugar and moisture content. The pods in stage 3 of maturity have a sweet flavor and a lower moisture content which is apropiate for drying. Mesquite pods have a heterogeneous and tortuous structure, which is a barrier that hinders the diffusion of moisture. This fact must be considered due to the increase in economic and energy costs when this drying process is carried out on a larger scale. The pods from Oaxaca and Durango must be dried at a minimum temperature of $60^{\circ} \mathrm{C}$ to obtain a quality dry product. The characteristic drying curve was deduced and it shows a good representation of drying kinetics. The mesquite pods are a multidomain food then the diffusion in a multidomain food must be studied.

\section{Acknowledgments}

The authors are grateful to Conacyt for the scholarship granted to Daniel López Cravioto, and the Instituto Politénico Nacional (Mexico) for SIP funding 20161016, 20170755 and 20180678. 


\section{Nomenclature}

Subscripts

$\begin{array}{ll}\text { c } & \text { Characteristic drying curve coefficient. } \\ \text { C } & \text { C Constant. } \\ \text { d } & \text { Characteristic drying curve coefficient. } \\ \text { dWr } & \text { Reduced drying rate. } \\ \text { dWref } & \text { Reference drying rate. } \\ \text { t } & \text { Time } \\ \text { W } & \text { Moisture content. } \\ \text { Weq } & \text { Equilibrium moisture content. } \\ \text { Wr } & \text { Reduced moisture content. }\end{array}$

\section{References}

[1] De La Rosa, A.P.; Hernández, J. T. F.; Portugal, V. O.; Castañeda, J. G. Processing, nutritional evaluation, and utilization of whole mesquite flour (Prosopis laevigata). Journal of food science 2006, 71(4), 315-320.

[2] Choge, S. K.; Pasiecznik, N. M.; Wright, J.; Awan, S.Z.; Harris, P.J.C. Prosopis pods as human food, with special reference to Kenya. Water SA. 2007,33(3).

[3] Grados, N.; Ruiz, W.; Cruz, G.; Díaz, C.; Puicón, J. Productos industrializables de la algarroba peruana (Prosopis pallida): Algarrobina y Harina de Algarroba. Multequina, 2000, 9(2), 119-132.

[4] Felker, P.; Grados, N.; Cruz, G.; Prokopiuk, D. Economic assessment of production of flour from Prosopis alba and P. pallida pods for human food applications. Journal of Arid Environments, 2003. 53(4), 517-528.

[5] Jannot, Y.; Talla, A.; Nganhou, J.; Puiggali, J. R. Modeling of banana convective drying by the drying characteristic curve (DCC) method. Drying technology, 2004. 22(8), 19491968.

[6] Meyer, D. Processing, utilization and economics of mesquite pods as a raw material for the food industry PhD Thesis. Techn. Wiss. ETH Zürich, 1984. 